\title{
TOWARD A STRATEGY OF POSITIVE ENDS
}

\section{Huba Wass de Czege}

Antulio J. Echevarria II

September 2001 